ISSN: 2581-8341

Volume 04 Issue 12 December 2021

DOI: 10.47191/ijcsrr/V4-i12-27, Impact Factor: 5.825

IJCSRR@ 2021

www.ijesrr.org

\title{
Analysis Corporate Entrepreneurship in SOEs at Mining Sector with Private Companies as Comparative Study
}

\author{
Mayta Kamila \\ School of Business and Management Institut Teknologi Bandung
}

\begin{abstract}
Competition between state-owned enterprises (SOEs) and private mining companies are getting bigger and stronger, but state-owned holding companies such as MIND ID have decreased performance due to several factors such as business focus and small business scale. This should be supported by the optimization of resources and the transformation of the competence of each employee to encourage the entrepreneurial spirit. This study was conducted to examine the corporate entrepreneurship culture in three state owned mining companies (PT. ABC, PT. DEF, and PT. GHI) and compared with private mining companies (PT. XYZ, PT. OPS, and PT. RTU). This study uses two methods, Entrepreneurial Orientation Survey (EOS) and Entrepreneurial Leadership Questionnaire (ELQ). EOS is used to measure corporate entrepreneurship culture and ELQ to see entrepreneurial characteristics in expected leadership and actual conditions of its implementation. EOS results show that the corporate entrepreneurship culture of mining SOEs has advantages in Cross-Functionality and Support to New Ideas while private mining companies have significantly higher Speed and Focus dimensions than mining SOEs. The ELQ results show that mining SOEs have the type of leadership in entrepreneurship (Miner type) and the leadership type of private mining companies in Explorer has a higher score than mining SOEs. Mining SOEs are advised to increase the dimensions of corporate entrepreneurship, one of which is by providing scholarships for employees taking magister program and creating a competition program that supports future innovation also the companies should provide training on corporate entrepreneurship.
\end{abstract}

KEYWORDS: Corporate Entrepreneurship, Mining, EOS, ELQ, Soes, Private Mining Companies

\section{INTRODUCTION}

In an era of globalization, business competition is getting bigger and tougher. This causes competition in every business to produce products and services and get more customers. State Owned Enterprises (BUMN) is one of the important economic activity actors in the national economy, together with other economic actors, namely the private sector (big-small, foreign domestic) and cooperatives (BUMN Dictionary). SOEs has 5 priorities, one of them is increasing economic value and social impact, especially in the fields of food security, energy, and health, restructuring business models through ecosystem development and collaboration, leading globally in strategic technology and institutionalizing digital capabilities, optimizing asset value, and educating and training the workforce, as well as developing quality human resources for Indonesia. The competition between private mining companies and the Ministry of State-Owned Enterprises (SOEs) is getting hotter, each party claims that the termination of the giant coal mine in Bumi Pertiwi is more suitable for them (Budiartie, 2019). From 2016-2019, the group of SOEs with an average profit of above 5 trillion, four SOEs experienced a downward trend in revenues such as electricity and gas procurement, mining and quarrying, construction and housing, and the processing industry (Saputra, 2021). Moreover, the problem arises because of which one will be more profitable for the state for the management of giant coal mines in the future. This causes SOEs to have more efforts and innovations to increase productivity. Therefore, a company's innovative mindset and strategy, especially its employees, are needed to be able to compete with start-up companies.

Entrepreneurship does not have to be owned by a new company but is also needed in developing companies. It's creating a new business or venture within an organization. Sometimes that business becomes a new section, or department, or even a subsidiary spinoff (Somers, 2018). Also entrepreneurship is considered to have a positive influence on organizational performance (Covin and Slevin, 1991). Innovation and strategic management in the management of SOEs are important in preconditions to improve the performance of SOEs and are the key to success in creating the right business environment. The Minister of SOEs, Erick Thohir said that the level of entrepreneurship in the country is still lower than in other countries in Southeast Asia (Putra, 2021). In SOEs, the culture that is instilled in its employees is AKHLAK BUMN, one of which is adaptive, which means constantly innovating to 


\section{International Journal of Current Science Research and Review}

ISSN: 2581-8341

Volume 04 Issue 12 December 2021

DOI: 10.47191/ijcsrr/V4-i12-27, Impact Factor: 5.825

IJCSRR@ 2021

wWw.i.jesrr.org

quickly adapt to changes in the work environment, enthusiastic and proactive in adapting and seeking solutions to any changes and new things, open to creativity that adds value to the progress of the organization, and proactively seeks opportunities to make improvements following developments. This supports that an entrepreneurial culture must be instilled in every SOE employee.

\section{CONCEPTUAL FRAMEWORK}

Organizational/Corporate culture describes the collectively shared values and norms of an organization's members. An organization's core values are a set of guiding principles to guide employees in achieving an organization's vision and fulfilling its mission. In a recent survey of almost 2,000 CEOs across the globe, the strategic leaders ranked culture as the most important value drive before operations, marketing, or finance (Rothermel, 2021). Based on John Brennan (2015), culture is a factor in the interactions between the people in that workplace. When organizational culture is managed well, the goodwill and trust that develops positions an organization and its people for greatness. He settled on five main factors of organizations that influence the organizational culture in Figure 1 which is aligned with SCARF model that involves five domains of human social experience: Status, Certainty, Autonomy, Relatedness, and Fairness (Rock, 2008). The five domains of the SCARF model are listed on the Leading Culture Model.

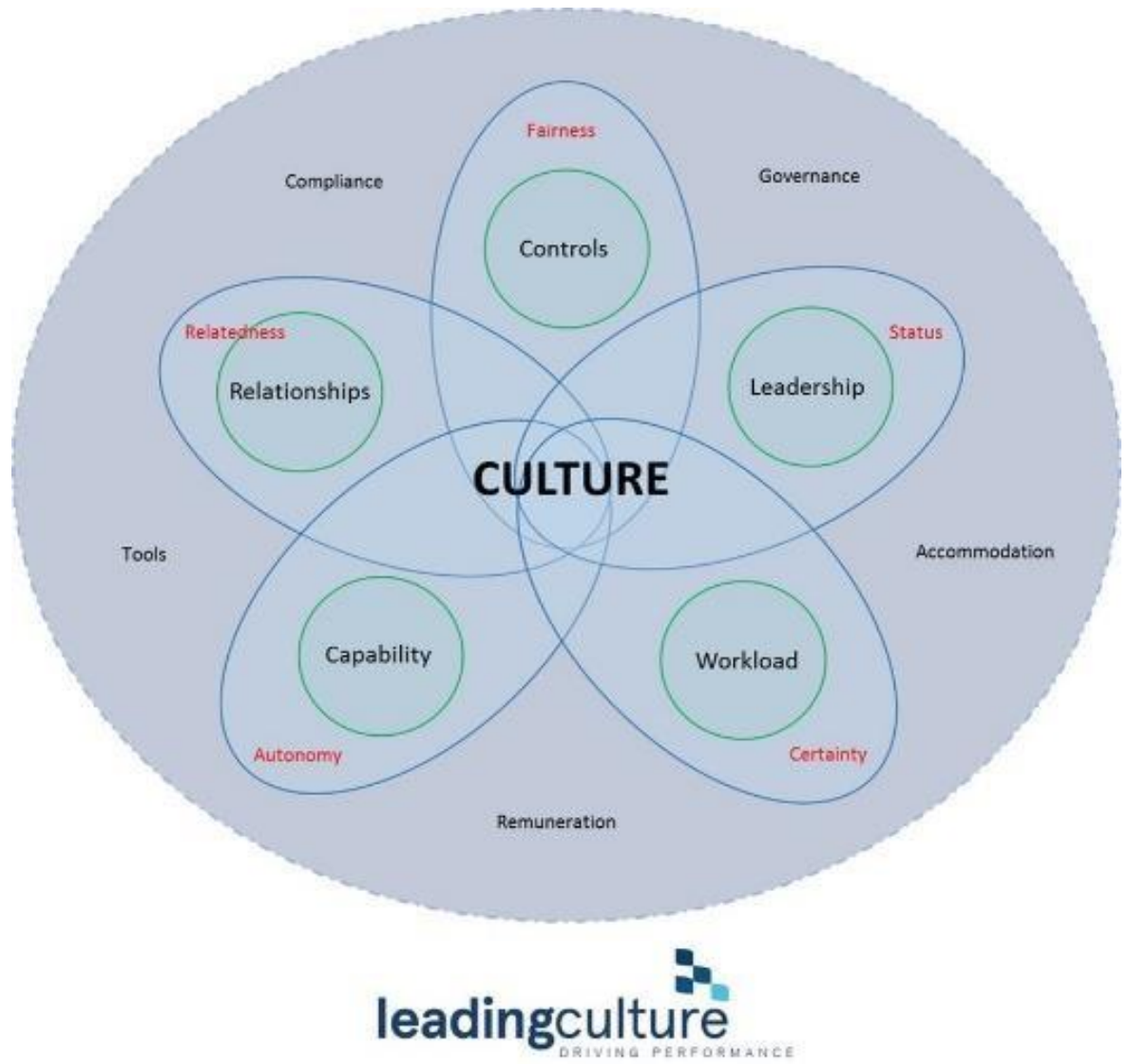

Figure 1. Leading Culture Model and SCARF Model

\section{EXPLORATION OF BUSINESS ISSUE}

From the explanation of the conceptual framework in Figure 1., the author has interviewed 6 companies, and each company divided by two factors, internal and external factors that happened recently in the company.

\section{A. PT. $A B C$}

PT. ABC is running a business in sector of gold, bauxite, and nickel mining. The company has a tall structure in which the highest decisions and commands rest with the president's director. Therefore, it takes a very long time to obtain the BOD approval. 


\section{International Journal of Current Science Research and Review}

ISSN: 2581-8341

Volume 04 Issue 12 December 2021

DOI: 10.47191/ijcsrr/V4-i12-27, Impact Factor: 5.825

IJCSRR@ 2021

WWw.ijesrr.org

Also, the coordination between PT. ABC's business units and the head office does not run well. External factors that affected the business of this company are the changes of forestry Law that always change and there are still illegal mines that cause the company to lose competitiveness with illegal mines.

\section{B. PT. DEF}

PT. DEF is running a business in the sector of coal mining. Due to the company's structure, it needs a long time to make a decision. The other issue is the coordination between divisions tends to be poor. The external factors is hard for the company to manage operating expenses and company profits following the Decree of the Minister of Energy and Mineral Resources No.255.K/30/MEM/2020 concerning the Fulfillment of Domestic Coal Needs 2021. PT. DEF also need to comply with other regulation such as the one regarding the environment.

\section{PT. GHI}

PT. GHI is running a business in the sector of tin mining. Internal factor is influenced by the low production of tin ore and high production costs. There are still many illegal mines in the PT GHI field area. This can cause a decrease in product supply at PT GHI itself. In addition, fluctuations in tin commodity prices also have an effect, especially when the price drops.

D. PT. XYZ

PT. XYZ is running a business in coal mining. Employees' dissatisfaction (e.g., dissatisfaction with the decisions of superiors, or certain expectations that have not been met by the company) as internal factors. And the external is about fluctuating coal prices.

\section{E. PT. OPS}

PT. OPS is running a business in coal mining. The internal factor that affected the performance of the company is that the company is over-optimistic in setting targets resulting in some projects are not being achieved. Plan Do Check Action is not carried out effectively. The external factors are the same with other coal mining companies, the company needs extra effort to stabilize production costs because the selling price abroad is higher than the local.

\section{F. PT. RTU}

PT. RTU is running a business in coal mining. The internal factors in this company are that employees are not appreciated by the company when making new innovations or achieving the target and the company also tends to maximize the potential that exists first rather than looking for new or making new products. Same with other coal mining, coal prices and government regulations regarding DMO is external factor.

Based on the exploration of the business issues of the six companies, we can see that the common problems that occur in SOEs and private companies in the mining sector are strong bureaucracy, unfavorable regulation and government policy, and fluctuations in mining prices. The problem point that can be highlighted from private companies is that companies give freedom to be creative and innovate, while in SOEs creativity will be hit by existing regulations or strong bureaucracy in stateowned enterprises. This can lead to a decrease in company performance if the company does not continue to innovate. One way to grow this is to foster corporate entrepreneurship which must be improved and developed. The hope is that within a certain period of time they can create new opportunities and overcome existing risks. Therefore, they must develop a company culture to encourage human resource capabilities, namely corporate entrepreneurship.

\section{LITERATURE STUDY}

Corporate entrepreneurship (Intrapreneurship) is a process used to develop new business, products, services, or processes inside of an existing organization to create value and generate new revenue growth through entrepreneurial thought and action (Corporateentreprenuers.com). Intrapreneurship was defined by Pinchot (1985) as "dreamers who do". He said that a growing company needs entrepreneurial thinking within the company. It makes companies able to create value through innovation and be able to seize opportunities without regard to human or capital resources (Pinchot, 1987).

Zahra and Covin (1995) evidenced that corporate entrepreneurship has a positive impact on financial measures of organizational performance. The authors contended that corporate entrepreneurship should not be regarded as a short-term solution but as a longterm strategy for achieving higher financial performance. In order to realize the full benefits of corporate entrepreneurship, managers 


\section{International Journal of Current Science Research and Review}

ISSN: 2581-8341

Volume 04 Issue 12 December 2021

DOI: 10.47191/ijcsrr/V4-i12-27, Impact Factor: 5.825

IJCSRR@ 2021

Www.ijesrr.org

must be willing to sustain their support for entrepreneurial initiatives over a number of years. Without such managerial support, corporate entrepreneurial activities may be discontinued long before they would reasonably be expected to financially benefit the corporation (Lai Hong Ng, 2020).

\section{ELQ and EOS}

Entrepreneurial Orientation Survey (EOS) was built to know what entrepreneurial companies look like, especially regarding some key metrics of entrepreneurial orientation. Understanding where a company is strong and where it is weak in its entrepreneurial orientation is a good place to start. The EOS diagnosis provides this starting point (Thornberry, 2006). Thornberry had formed The 7Fs for the basis of EOS. The 7s described as high in entrepreneurial orientation or opportunistic, a company must score relatively well on the following dimensions: fast, flexible, focused, friendly, frugal, far-reaching, and futuristic. However, the EOS survey has been slightly modified from the original 7Fs assessment. It now includes General, Strategic Planning, Cross functionality, Support for New Ideas, Market Intelligence, Risk Aversion, Speed, Flexibility, Focus, Future Orientation.

Fast (Speed): Speed is determined by how well the company reacts to new opportunities that are related to the speed in making decisions, human resources allocation, and offered product delivery.

Flexible: Flexibility is related to the ability of the company to change the strategy to cope with the competition. This category also describes the company's capability to motivate employees and resources quickly to capture a new market opportunity as essential to success. This dimension is also included in the Cross-Functionality category in EOS. The Cross-Functionality category aims to see how fluid the organization of the divisions in the company is to work and solve problems.

Focused: Focused determine how focused the company is to achieve the goals. The company must plan and create a structure to achieve the goals. At the same time, they must be open to important opportunities that enter their field of vision.

Friendly: Friendly determine how friendly the company is to internal and external consumers and to its own employees, so this dimension includes Market Intelligence. In internal, the company should be able to bring harmony between the individuals among divisions which also include in Cross Functionality Category.

Frugal: Frugal means how wise a company in spend money to execute a strategy. This dimension is needed on reducing costs according to plan while benefiting from the new opportunity to grow. This dimension describes in General Category and Support New Ideas Category.

Far Reaching: The far-reaching characteristic is to show whether the company is accessible or not in the market. A more accessible company to the customer will make the company easier to access the market and promote.

Futuristic: Futuristic describes how a company sees and prepares for the future. The company is able to anticipate the new market, outside of its current market base.

Some categories that are not included in the $7 \mathrm{Fs}$ and categories of EOS such as Personal Orientation, Current Condition of Company, and Employee's Knowledge about Entrepreneurship as supporting data to improve analysis of corporate entrepreneurial in the company.

General: The tightness of financial and budgeting control, as well as a section that asks respondents to describe their own entrepreneurial orientation.

Personal Orientation: It shows how individuals react to the entrepreneurial environment in the company. The higher the value means that employees support and like the entrepreneurial environment.

Condition of the company: It shows how well the company supports the employees in the company in terms of empowering employees, supporting innovation, and salary. It will affect employees' morale which may promote an entrepreneurial environment within the company.

Employees Knowledge: A higher score means knowledge of entrepreneurship and the desire to become an entrepreneur in a high company. This will make it easier for the company to increase the entrepreneurial mindset of each employee in the company.

Thornberry also developed tools to create entrepreneurial leadership to be owned by the management, called the Entrepreneurial Leadership Questionnaire (EQL) which is a questionnaire that needs to be answered by the direct subordinate of the said leader. The first response (Importance) is to measure how important that statement is to their direct line of works. The second response (Frequency) is to find out how often the statement is completed by his superior in the office. Thornberry then developed the concept to conduct research that there are different types of entrepreneurial leaders as describe on below figure. 


\section{International Journal of Current Science Research and Review}

ISSN: 2581-8341

Volume 04 Issue 12 December 2021

DOI: 10.47191/ijcsrr/V4-i12-27, Impact Factor: 5.825

IJCSRR@ 2021

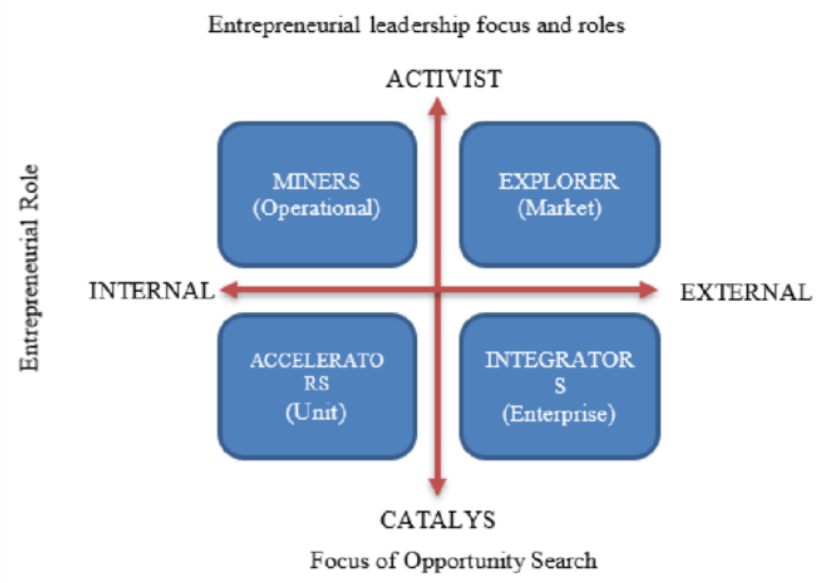

Figure 2. Entrepreneurial Leadership Focus and Role

Explorers: Explorers are as close to start-up entrepreneurs as you will find among corporate entrepreneurs. They identify, shape, and capture new business opportunities, but within an existing organization.

Miners: Miners are focused on operations, they had significant opportunities to create value for the company as a whole, beyond the bottom line. The leaders are making to get lower cost in running a business to create better value for customers.

Accelerators: Accelerators are focused on two types of value creation, so they try hard to engage their employees in the process. Accelerators view their roles as coaches and catalysts in freeing the creative potential of their employees.

Integrators: Integrators are entrepreneurial leaders at the enterprise level who focus on the total organization or a major part of it. They are very externally focused but they are more interested to create an entrepreneurial organization and then just chasing the potential opportunity.

\section{RESEARCH METHODOLOGY}

The data gathered in this research are primary data and secondary data. Primary data were obtained directly from respondents using a questionnaire from the EOS and ELQ surveys. The questionnaire is a technique of collecting data from a set of questions that must be answered by respondents by multiple-choice that using Likert's Scale. This questionnaire has been distributed to 135 employees in SOEs and 120 employees in private mining companies. Respondents are classified by gender, age, experience, and level in company.

Based on Appendix A, respondents are dominated by men because the research was conducted in mining companies where there are more men than women. If we look at the number of employees in the company, respondents are dominated by level staff from the six companies. This is because in a company the total number of employees is dominated by the staff level compared to the manager and director level. This is also seen in the number of respondents' experience, which is dominated by 1-5 and 5-10 years.

\section{Variable Measurement Technique}

The questionnaire in this study used a Likert scale to measure attitudes, opinions, and perceptions of a person or group of people about social phenomena. The Likert scale in this research using ordinal measurement which ranked the level of EOS and ELQ developed by Thornberry (2006), there are:

1 = very disagree, 2 = disagree, $3=$ neutral, 4 = agree, 5 = very agree.

Then after the data is collected, the data is processed to determine conclusions from the measured dimension for each company and presented in the form of a radar diagram and then interpreted the results.

\section{Validity and Reliability Data}

Based on Neal Thornberry, the validity and reliability of EOS and ELQ have been tested in big companies and also by many researchers after Thornberry. The validity of this method can be identified based on the value of the correlation coefficient between the item score and the total score at the significant level of $5 \%$. Then, the items which are not correlated will be automatically 


\section{International Journal of Current Science Research and Review}

ISSN: 2581-8341

Volume 04 Issue 12 December 2021

DOI: 10.47191/ijcsrr/V4-i12-27, Impact Factor: 5.825

IJCSRR@ 2021

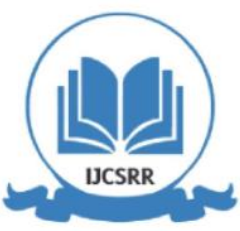

www.ijesrr.org

eliminated. This method has been used several times in research and has been tested for validation and reliability. The validity of EOS for all questions is valid (Haqqani, 2014).

Reliability tests are used to determine whether the instrument is trusted or not, and ensure that the method does not have a bias error. The reliability test of EOS is determined by using Cronbach's Alpha coefficient. This coefficient is used in all methods which is a description of the variation of items for evaluation of internal consistency. Referring to the last project of Illaya Haqqani (2014) that this instrument has been tested so that all data are reliable.

\section{BUSINESS ALTERNATIVES AND SOLUTIONS}

The authors analyze the conclusions that can be drawn in each category that is measured, and then the results are compared in each mining SOE and private mining company.

\section{Analysis and Interpretation of EOS}

Results of EOS calculation each dimension from SOEs and private mining companies.

Table 1. EOS Result in each category an company

\begin{tabular}{|l|l|l|l|}
\hline No & Category & SOEs & Private Company \\
\hline 1 & Strategy Planning & 3.32 & 3.20 \\
\hline 2 & Cross Functionality & 3.68 & 3.58 \\
\hline 3 & Support to new ideas & 3.67 & 3.50 \\
\hline 4 & Market Intelligence & 3.43 & 3.43 \\
\hline 5 & Risk & 3.32 & 3.49 \\
\hline 6 & Speed & 3.39 & 3.63 \\
\hline 7 & Flexibility & 3.37 & 3.41 \\
\hline 8 & Focus & 3.58 & 3.69 \\
\hline 9 & Future Orientation & 3.00 & 3.24 \\
\hline
\end{tabular}

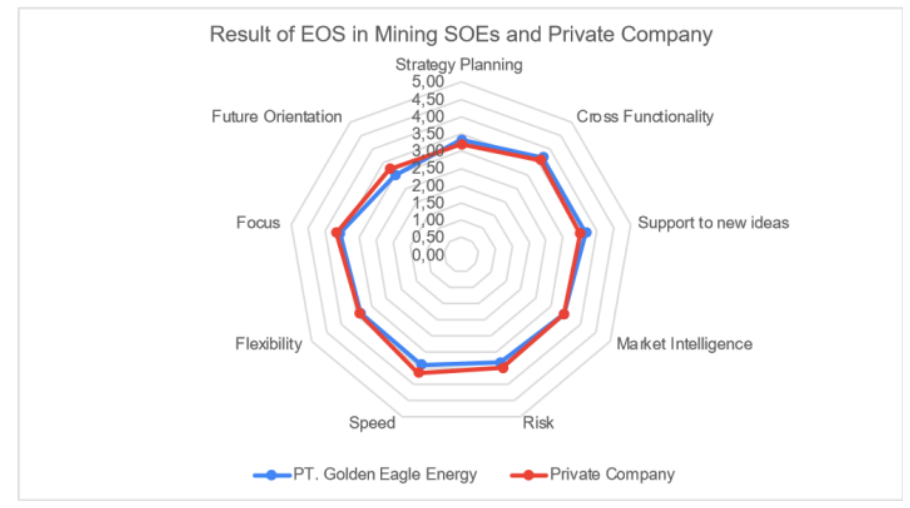

Figure 3. Result of EOS in Mining SOEs and Private Company

From Table 1 we get that corporate entrepreneurship's dimension at Mining SOEs company which has the highest point is CrossFunctionality, followed by Support to New Ideas, Focus, Market Intelligence. Meanwhile, private mining companies have the highest points in Focus, followed by Speed, Cross-Functionality, and Support to New Ideas. And the most significant difference between mining SOEs and private mining SOEs is in the speed dimension and future orientation.

\section{A. Strategic Planning}

In this category, there are 5 statements that direct how companies make strategies from planning, methods, to guidelines used in planning strategies. As shown in Appendix 2, the average score in mining SOEs is 3.32 and private mining companies are 3.2. This shows that mining SOEs has a dimension of strategic plan better than private mining companies. Because mining SOEs are 


\section{International Journal of Current Science Research and Review}

ISSN: 2581-8341

Volume 04 Issue 12 December 2021

DOI: 10.47191/ijcsrr/V4-i12-27, Impact Factor: 5.825

IJCSRR@ 2021

WWw.ijesrr.org

compliant to regulations and rules that have been made. It is supported that the mining SOEs use a formal strategic planning process so that the company expects managers to be guided by the annual budget plan. A director from a private company stated that the checking process in the company was not done properly because the relationship between employees and superiors tends to be close. This makes this culture have a lower score in private mining companies than mining SOEs.

\section{B. Cross Functionality}

Cross functionality serves to determine the relationship between divisions and work functions in the company. The entrepreneurial culture is in the cross-functionality category in mining SOEs has an average score of 3.68 and private mining companies are 3.58. It shows that mining SOEs have better coordination between divisions and departments than private mining SOEs. Because in stateowned companies that have many units, employees will be rotated or new assignments will be made every time the level increases so that employees will get a good experience and make it easier for employees to coordinate between units.

\section{Support to New Ideas}

Support new ideas category aims to find out the company's support in making innovations. The score in mining SOEs gets 3.67 and private mining companies is 3.49. Mining SOEs tend to have a well-functioning brainstorming tool for capturing new ideas that have a higher score than private mining companies. The presence of holding SOEs also helps and supports to continue to carry out good innovations and add value to the company.

\section{Market Intelligence}

This category aims to position the company in the market, plan to gain the market share, and stay in the market competition. Mining companies in Indonesia show a high commitment to serving customers. Top management in mining SOEs often visits customers directly rather than in private mining companies. Private mining companies tend to take concern on customers only in their top management, and also the respondents consist of many staff level so they didn't know whether the top management meets the customers directly or not. They also publish the result of satisfaction surveys internally, so that customer satisfaction is not only known by the sales division but all divisions in the company.

\section{E. Risk Aversion}

The risk aversion category identifies the company's courage when taking risks as a reflection of the company's entrepreneurship. The result shows that private mining companies are not afraid to invest in new businesses, which is indicated by a higher score than in mining SOEs. This is probably due to the many regulations in SOEs so that it is difficult for companies to set aside some funds to invest in new businesses, as in the previous dimension, the management press is a quite tight budget and requires approval stages to be accepted.

\section{F. Speed}

Speed category identifies how fast the company to responds the opportunity and also the problems. In Appendix 2, the entrepreneurial culture in the Speed Category, in mining SOEs have a lower score than private mining companies. In SOEs, it can be seen from the tall organizational structure, it shows that the highest decision is in the main director which causes decision-makers in this company to tend to be slower than the private sector. In addition, there are still many bureaucracies and regulations that hampered the performance. SOEs mining companies tend to be judged as companies that are slower than private mining companies. This is probably caused by unstable income, many mining fields owned by private companies compared to mining SOEs so that the consumer image assumes that the mining SOEs is not fast.

\section{G. Flexibility}

Flexibility is a category to measure the ability of the company to change the strategy to cope with the competition, respond to the opportunity, and empower employees. Appendix 2 shows that the flexibility of private mining companies is higher than mining SOEs. Mining SOEs tend to slower allocate the opportunity business than private mining companies. Because in SOEs there are many steps to take the opportunity and have intense bureaucracy.

\section{H. Focus}

This category measures the company's focus on executing activities, strategies, and plans. The result shows that private mining companies have a better focus on a clear vision and mission than mining SOEs. Mining SOEs will spend funds for the right things 


\section{International Journal of Current Science Research and Review}

ISSN: 2581-8341

Volume 04 Issue 12 December 2021

DOI: 10.47191/ijcsrr/V4-i12-27, Impact Factor: 5.825

IJCSRR@ 2021

Www.ijcsrr.org

and related work so that the company remains focused on the planned strategy because the company tends to set the budget plan and focus on the business rather than take the other opportunity. Moreover, the strategy was not followed by the socialization of the plan, so it was not well socialized so that we would get different answers if we asked about the corporate strategy to two different people.

\section{Future Orientation}

The future orientation category measures the company's attitude to view and prepares for the future with entrepreneurial behavior achievement. Employees in private mining companies consider their companies to be at the forefront of their fields rather than in mining SOEs. And also, in mining SOEs are still hesitant in creating innovative new products that consumers themselves do not know if they need it. In addition, they also doubt that the company's position is likely to be a follower or a leader in their product offerings.

The next four analyses are supporting the analysis of the 9 dimensions that have been analyzed and interpreted.

\section{J. General}

It is shown that the mining SOEs adhere strictly to budgetary controls rather than in private mining companies. This behavior is assumed that it does not support the entrepreneurial culture in the company because it limits employees to innovate which is not profitable so that many stages to get investment approval outside the budget also gets high points. This supports the dimensions of speed and flexibility where mining SOEs have a lower value than private companies.

\section{K. Individual Orientation}

The individual orientation in entrepreneurial culture in mining SOEs is higher than in private mining companies. It means that the willingness to be individual entrepreneurship is quite high, but this is hampered by company regulations, bureaucracy, and other things that prevent employees from being creative and innovating.

\section{Company Condition}

The individual orientation in entrepreneurial culture in mining SOEs is higher than in private mining companies. It means that the willingness to be individual entrepreneurship is quite high, but this is hampered by company regulations, bureaucracy, and other things that prevent employees from being creative and innovating. Employees in mining SOEs attach great importance to fair and definite salaries so that they carry out their work by giving their best. However, many employees in private companies are still more comfortable in a relatively structured and orderly environment so they are hesitant to ask questions and change the status quo in the company.

\section{Employee's Knowledge}

The result shows that employees in mining SOEs and private mining companies have high confidence that entrepreneurs can learn a lot about how to become an entrepreneur and succeed from the learning outcomes. This shows that their initial knowledge of entrepreneurs is quite high. But they are not sure that they are creative in their work. This is because the company's many and strict systems and regulations make them unable to explore many things to become creative people.

\section{Analysis and Interpretation of ELQ}

Data were taken by six companies with targets from staff level to manager or supervisor level. Respondents were asked to rate their immediate supervisor. The results of this survey are shown in Table 3 which is grouped by dimensions of entrepreneurial leadership, there are Explorer, Miner, Accelerator, Integrator. The results of the ELQ survey are shown in Table 2.

Based on the data in Table 4 above, the greater the difference between the two indicates that there is a lack of practice in running entrepreneurial leadership which employees think is very important. The percentage data shows that three stateowned mining companies have the entrepreneurial leadership type of miner. And private mining companies have explorer type. Figure 3.2 shows that mining SOEs has significantly different in explorer type with private mining companies.

\section{A. Explorer}

The differences between mining SOEs and private mining companies are significant in this type. This is because private mining companies tend to look at the market compared to mining SOEs. This is also supported by several prominent dimensions of corporate 


\section{International Journal of Current Science Research and Review}

ISSN: 2581-8341

Volume 04 Issue 12 December 2021

DOI: 10.47191/ijcsrr/V4-i12-27, Impact Factor: 5.825

IJCSRR@ 2021

www.ijesrr.org

entrepreneurship culture, such as flexibility and market intelligence. This dimension shows that private mining companies are more flexible in following existing market trends and trying to take existing opportunities.

Table 2. ELQ Result in Mining SOEs and Private Mining Company

\begin{tabular}{|l|c|l|l|}
\hline \multicolumn{2}{|c|}{ Type } & Mining SOEs & Private Mining Companies \\
\hline Explorer & I & 37,24 & 37,51 \\
\hline & F & 31,37 & 34,45 \\
\hline & Difference & 5,87 & 3,07 \\
\hline & F/I & 84,28 & 91,77 \\
\hline Miner & I & 31,68 & 30,17 \\
\hline & F & 27,60 & 26,65 \\
\hline & Difference & 4,08 & 3,53 \\
\hline & F/I & 86,90 & 88,47 \\
\hline Accelerator & I & 45,25 & 43,17 \\
\hline & F & 39,34 & 37,38 \\
\hline & Difference & 5,90 & 5,79 \\
\hline & F/I & 86,88 & 86,62 \\
\hline Integrator & I & 54,62 & 53,21 \\
\hline & F & 46,96 & 46,39 \\
\hline & Difference & 7,66 & 6,82 \\
\hline & F/I & 85,88 & 87,15 \\
\hline & & &
\end{tabular}



Figure 4. ELQ Result in Mining SOEs and Private Company

\section{B. Miner}

Mining SOEs show a high enough frequency result so that the percentage yield $(\mathrm{F} / \mathrm{I})$ of this type is higher than private mining companies. It shows that mining SOEs tend to increase the value of the company by fixing and optimizing internal company. It is supported by dimensions of entrepreneurial culture such as cross-functionality that have the highest score.

\section{Accelerators}

The percentage (F/I) in mining SOEs is higher than in private mining companies. It shows that in mining SOEs, the leaders always motivate and encourage their employees to find new and innovative ways of working. It is assumed that mining SOEs have KPI (Key Person Indicator) that is used as an employee has carried out his obligations and the conditions that must be met. Therefore, leaders tend to direct subordinates according to a predetermined task. 


\section{International Journal of Current Science Research and Review}

ISSN: 2581-8341

Volume 04 Issue 12 December 2021

DOI: 10.47191/ijcsrr/V4-i12-27, Impact Factor: 5.825

IJCSRR@ 2021

Www.ijesrr.org

\section{Integrators}

This type shows the percentage $(\mathrm{F} / \mathrm{I})$ in private mining companies is higher than mining SOEs. This shows that private mining companies are generally leaders who are less active in talking about the company's future, fighting bureaucracy, not supporting rebellious type employees, and lacking in concrete actions to implement improvement suggestions.

\section{CONCLUSIONS}

Corporate entrepreneurship in mining SOEs has advantages in the dimensions of Cross-Functionality and Support to New Ideas. Cross-Functionality has a few differences from private mining companies. Because companies in the mining sector need good cooperation from downstream to upstream processes, for example, the exploration division must exist to issue a number of resources and reserves for the mine planning division. So that coordination between divisions and departments is needed in mining sector companies to run businesses from exploration to production.

Private mining companies have a lower score than mining SOEs, because private companies tend to instill creativity in all employees so that there is no special division to innovate the company. In addition, it is possible that leaders in this company have a large portion to seek new business opportunities.

A very significant difference occurs in the speed dimension, private mining companies have higher speed than mining SOEs. This is because private mining companies are not controlled by the government and are faster in decision-making because the company's bureaucracy tends to be less complex than SOEs mining companies. And mining SOEs tend to be careful in making decisions that are outside the budget.

Mining SOEs and private mining companies have a weakness in future orientation dimensions and strategic planning. Future Orientation is the lowest dimension in the mining companies in Indonesia. This is because mining companies are companies that are trying only to explore natural resources. They also have not invested in R\&D so many employees have not planned for the future properly. It is possible they do not have a place to think about future plans or innovations aimed at the future of the company.

Strategic Planning is a dimension that needs to be improved in state-owned and private mining companies. This is because of mining companies conduct strategic planning every 5-10 years in accordance with mine planning, with a race from the previous year and usually, they only change parts of the mining process and do not differ so that the level of innovation possessed by employees is not optimal.

ELQ analysis shows that the current managerial characteristic in mining SOEs is Miner. While in private mining companies, the managerial characteristic of the current condition is Explorer. Private companies tend to be more flexible in finding new business opportunities and they have not listed companies so they are not controlled by the public. Private mining companies tend to show their desire to be able to follow the existing market.

\section{RECOMMENDATIONS}

Based on the results of EOS and ELQ, it is recommended that the companies should provide a scholarship to the employee to study in magister program to invest in R\&D and also make a competition that aims to encourage the spirit of innovation in the organization. This competition should be based on favorable conditions for the company's future business so that it can continue to think about future plans and evolve into a better business entity. Also, it would be better if the company's strategic planning is carried out every year to minimize risk, and financial transparency is highly needed so that all employees have more confidence in the company. In addition, to improve these core values in entrepreneurial characteristics within the company, training related to the development of entrepreneurial characteristics needs to be trained to all levels of employees within the company, and to increase the speed dimensions, the company should analyze the personality of each employee and evaluate every month how the employee's performance affects the employee's personality.

\section{REFERENCES}

1. Brennan, J. (2015). Five key factors that determine organizational culture. April 20. Available from http://www.leadingculture.com.au/five-key-factors-thatdetermine-organisational-culture/ [Accessed on November 15 2021]. 


\section{International Journal of Current Science Research and Review}

ISSN: 2581-8341

Volume 04 Issue 12 December 2021

DOI: 10.47191/ijcsrr/V4-i12-27, Impact Factor: 5.825

IJCSRR@ 2021

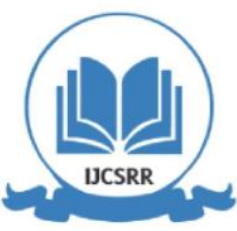

www.ijesrr.org

2. Budiartie, G. (2019). Swasta vs BUMN Makin Panas, Berebut Tambang Batu Bara RI. CNBC Indonesia. https://www.cnbcindonesia.com/market/2019060219301717-76505/swasta-vs-bumn-makin-panas-berebut-tambangbatubara-ri

3. Covin, J. G., \& Slevin, D.P., 1986, The development and testing of an organization-level entrepreneurship scale, in Ronstandt, R. et al. (Eds), Frontiers of Entrepreneurship Research, Babson College, Wellesley, M.A., pp. 629-39

4. Covin, J. G., 1991, Entrepreneurial vs conservative firms: a comparison of strategies and performance, Journal of Management Studies. Vol. 25 No. 5, pp. 439-62.

5. Haqqani, I., 2014, Corporate Culture Analysis Based on Entrepreneurship Case Study: PT.Mekar Makmur, Library ITB : Last Project

6. Hong, L., n.d, Corporate Entrepreneurship, Goodfellow publisher, Available from https://www.goodfellowpublishers.com/free_files/Chapter\% 206-f75896ab4ae78d6de2333426f72069ed.pdf [Accessed on November 2, 2021]

7. Pinchot III, G., 1985, Intrapreneuring: Why you don't have to leave the corporation to become an entrepreneur. Urbana,

8. IL: University of Illinois at Urbana-Champaign's Academy for Entrepreneurial Leadership Historical Research Reference in Entrepreneurship.

9. Pinchot, G., 1987, Innovation Through Intrapreneuring, Research Management, Vol.30 No.2. p. 14-19

10. PT. ABC, Tbk. 2020, Annual Report, Jakarta.

11. PT. DEF, Tbk. 2020, Annual Report, Jakarta.

12. PT. GHI, Tbk. 2020, Annual Report, Jakarta. Putra, D. A. (2021). Jumlah Wirausaha Indonesia Jauh di Bawah Malaysia dan Thailand. Merdeka. https://www.merdeka.com/uang/jumlah-wirausahaindonesia-jauh-di-bawah-malaysia-dan-thailand.html

13. Rothermel, F. T. (2021). Strategic Management, In McGraw-Hill Education. Organizational Design: Structure, Culture, and Control, 291-428.

14. Saputra, Dany. (2021). Utang BUMN Kian Meningkat Selama 6 Tahun Terakhir. Bisnis.com.

15. https://ekonomi.bisnis.com/read/20210324/9 /1372103/utang-bumn-kian-meningkat-selama-6-tahun-terakhir

16. Somers, M. (2018). Intrapreneurship, explained. MIT Management. https://mitsloan.mit.edu/ideas-madetomatter/intrapreneurship-explained

17. Thornberry, N. (2006). Lead Like an Entrepreneur. McGraw Hills.

18. Zahra, S. A., \& Covin, J. G. (1995). Contextual influences on the corporate entrepreneurship-performance relationship: A longitudinal analysis. Journal of Business Venturing, 10(1), 43-58. 
International Journal of Current Science Research and Review

ISSN: 2581-8341

Volume 04 Issue 12 December 2021

DOI: 10.47191/ijcsrr/V4-i12-27, Impact Factor: 5.825

IJCSRR@ 2021

www.ijesrr.org

\section{APPENDIX I}

Respondents Classification

\begin{tabular}{|c|c|c|c|c|c|c|c|}
\hline \multicolumn{2}{|l|}{ Company } & $\begin{array}{l}\text { PT. } \\
\text { ABC }\end{array}$ & $\begin{array}{l}\text { PT. } \\
\text { DEF }\end{array}$ & $\begin{array}{l}\text { PT. } \\
\text { GHI }\end{array}$ & $\begin{array}{l}\text { PT. } \\
\text { XYZ }\end{array}$ & $\begin{array}{l}\text { PT. } \\
\text { OPS }\end{array}$ & $\begin{array}{l}\text { PT. } \\
\text { RTU }\end{array}$ \\
\hline \multicolumn{2}{|l|}{ Total of respondent } & 30 & 29 & 36 & 29 & 33 & 27 \\
\hline \multirow{2}{*}{ Gender } & Man & 17 & 22 & 28 & 22 & 27 & 22 \\
\hline & Woman & 13 & 7 & 8 & 7 & 6 & 3 \\
\hline \multirow{5}{*}{ Age (years) } & $23-30$ & 13 & 20 & 10 & 15 & 7 & 10 \\
\hline & $31-35$ & 4 & 2 & 3 & 5 & 3 & 4 \\
\hline & $36-40$ & 7 & 1 & 8 & 4 & 9 & 5 \\
\hline & $41-45$ & 2 & 1 & 7 & 3 & 6 & 3 \\
\hline & $>45$ & 4 & 6 & 8 & 2 & 8 & 5 \\
\hline \multirow{4}{*}{ Experiences (years) } & $1-5$ & 12 & 8 & 10 & 12 & 7 & 11 \\
\hline & $>5-10$ & 6 & 11 & 4 & 10 & 14 & 7 \\
\hline & $>10-15$ & 8 & 3 & 9 & 3 & 4 & 4 \\
\hline & $>15$ & 4 & 7 & 13 & 4 & 8 & 5 \\
\hline \multirow{5}{*}{ Level in Company } & Staff & 20 & 14 & 10 & 16 & 19 & 15 \\
\hline & Supervisor & 5 & 11 & 10 & 5 & 3 & 5 \\
\hline & $\begin{array}{l}\text { Senior } \\
\text { Manager }\end{array}$ & 2 & 5 & 12 & 3 & 4 & 3 \\
\hline & $\begin{array}{l}\text { General } \\
\text { Manager }\end{array}$ & 1 & 0 & 1 & 2 & 3 & 3 \\
\hline & Director & 1 & 0 & 3 & 0 & 4 & 1 \\
\hline
\end{tabular}

\section{APPENDIX II}

EOS Result in each category in mining SOEs and private mining company

\begin{tabular}{|l|l|l|l|}
\hline No. & Strategic Planning Category & Mining SOEs & $\begin{array}{l}\text { Private } \\
\text { Company }\end{array}$ \\
\hline 1 & Utilizes a formal strategic planning process. & 4,24 & 4,05 \\
\hline 2 & Let strategy evolve based on trends in the marketplace & 3,96 & 4,07 \\
\hline 3 & $\begin{array}{l}\text { Expects managers to stick closely to the yearly plans } \\
\text { and budgets }\end{array}$ & 4,18 & 4,01 \\
\hline 4 & Doesn't have clear strategy & 1,70 & 1,59 \\
\hline 5 & $\begin{array}{l}\text { Relies heavily on outside consultants for developing } \\
\text { strategy }\end{array}$ & 2,53 & 2,29 \\
\hline & \begin{tabular}{l} 
Score \\
\hline
\end{tabular} & 3,32 & 3,20 \\
\hline
\end{tabular}




\section{International Journal of Current Science Research and Review}

ISSN: 2581-8341

Volume 04 Issue 12 December 2021

DOI: 10.47191/ijesrr/V4-i12-27, Impact Factor: 5.825

IJCSRR@ 2021

wWw.i.jesrr.org

\begin{tabular}{|l|l|l|l|}
\hline No. & Cross-Functionality Category & Mining SOEs & $\begin{array}{l}\text { Private } \\
\text { Company }\end{array}$ \\
\hline 1 & Has very few cross-functional silos (interdepartmental barriers) \\
\hline 2 & $\begin{array}{l}\text { Has departments that willingly share ideas and information } \\
\text { with each other }\end{array}$ & 2,87 & 3,00 \\
\hline 3 & $\begin{array}{l}\text { Encourages cross-functional discussion and problem solving } \\
4\end{array}$ & Formally rewards cross-functional cooperation & 3,16 \\
\hline 5 & $\begin{array}{l}\text { Rotates employees through different functions as part of a } \\
\text { formal employee development process. }\end{array}$ & $3,7,79$ & 4,08 \\
\hline & \begin{tabular}{l} 
Mean \\
\hline
\end{tabular} & 3,68 & 3,44 \\
\hline
\end{tabular}

\begin{tabular}{|l|l|l|l|}
\hline No. & Support to New Ideas & Mining SOEs & $\begin{array}{l}\text { Private Mining } \\
\text { Company }\end{array}$ \\
\hline 1 & $\begin{array}{l}\text { Management generally encourages us to think up new and different } \\
\text { ways of doing things }\end{array}$ & 4,19 & 4,03 \\
\hline 2 & $\begin{array}{l}\text { There is one major function in our organization, which is primarily } \\
\text { responsible for innovation }\end{array}$ & 4,03 & 3,52 \\
\hline 3 & $\begin{array}{l}\text { If you agree with the statement above, the department has developed } \\
\text { and is carrying out its functions to the maximum extent possible }\end{array}$ & 3,67 & 3,48 \\
\hline 4 & $\begin{array}{l}\text { We have a suggestion method in place, which works well in } \\
\text { capturing employee ideas }\end{array}$ & 3,76 & 3,56 \\
\hline 5 & $\begin{array}{l}\text { The organization does not take kindly to challenging the way things } \\
\text { are done around here. }\end{array}$ & 2,76 & 2,88 \\
\hline 6 & We often meet informally to discuss new business ideas & 3,63 & 3,46 \\
\hline & Mean & 3,67 & 3,49 \\
\hline
\end{tabular}

\begin{tabular}{|c|c|c|c|}
\hline No. & Market Intelligence & Mining SOEs & $\begin{array}{l}\text { Private Mining } \\
\text { Company }\end{array}$ \\
\hline 1 & The customer is king in our organization. & 4,16 & 4,07 \\
\hline 2 & $\begin{array}{l}\text { Unless you are in sales or marketing, there is very little } \\
\text { encouragement to meet with customers. }\end{array}$ & 3,14 & 3,26 \\
\hline 3 & $\begin{array}{l}\text { The company routinely gives customer satisfaction surveys and } \\
\text { publishes the results internally for all of us to see. }\end{array}$ & 3,72 & 3,38 \\
\hline 4 & Senior executives rarely visit customers directly. & 2,65 & 2,81 \\
\hline \multirow[t]{2}{*}{5} & $\begin{array}{l}\text { Most of our employees know who our closest competitors are } \\
\text { and how we stack up against them. }\end{array}$ & 3,50 & 3,65 \\
\hline & Mean & 3,43 & 3,43 \\
\hline
\end{tabular}




\section{International Journal of Current Science Research and Review}

ISSN: 2581-8341

Volume 04 Issue 12 December 2021

DOI: 10.47191/ijcsrr/V4-i12-27, Impact Factor: 5.825

IJCSRR@ 2021

WwW.ijesrr.org

\begin{tabular}{|c|c|c|c|}
\hline No. & Risk Aversion & Mining SOEs & $\begin{array}{l}\text { Private Mining } \\
\text { Company }\end{array}$ \\
\hline 1 & Our company is proud of its conservative heritage and orientation & 2,62 & 2,81 \\
\hline 2 & We are careful not to make mistakes & 4,09 & 4,23 \\
\hline 3 & $\begin{array}{l}\text { We are not afraid to invest in new ventures on an intuitive gut } \\
\text { feeling rather than based on careful analysis }\end{array}$ & 2,87 & 3,25 \\
\hline 4 & $\begin{array}{l}\text { People generally have a lot of latitude in the organization to try } \\
\text { new things and fail }\end{array}$ & 3,09 & 3,37 \\
\hline 5 & $\begin{array}{l}\text { We talk a lot about the need for greater risk taking in our } \\
\text { organization, but the reality is people who try and fail don't last } \\
\text { very long. }\end{array}$ & 3,03 & 3,05 \\
\hline \multirow[t]{2}{*}{6} & We prefer to grow in a planned and controlled manner. & 4,17 & 4,22 \\
\hline & Mean & 3,31 & 3,49 \\
\hline
\end{tabular}

\begin{tabular}{|l|l|l|l|}
\hline No. & Speed Category & Mining SOEs & Private Mining Company \\
\hline 1 & Customer complaints are handled quickly and efficiently & 4,06 & 4,25 \\
\hline 2 & Problems do not get solved quickly. & 2,64 & 2,50 \\
\hline 3 & $\begin{array}{l}\text { Managers have a great deal of autonomy in making } \\
\text { decisions. }\end{array}$ & 3,54 & 3,80 \\
\hline 4 & Customers describe us as a feet moving company & 3,34 & 3,99 \\
\hline 5 & Mean & 3,39 & 3,63 \\
\hline
\end{tabular}

\begin{tabular}{|l|l|l|l|}
\hline No. & Focus Category & $\begin{array}{l}\text { Mining } \\
\text { SOEs }\end{array}$ & $\begin{array}{l}\text { Private Mining } \\
\text { Company }\end{array}$ \\
\hline 1 & We do few things, but do them well. & 3,56 & 3,80 \\
\hline 2 & $\begin{array}{l}\text { We are a fragmented-organizations, the right hand seldom knows } \\
\text { what the left hand is doing. }\end{array}$ & 2,78 & 2,96 \\
\hline 3 & $\begin{array}{l}\text { Senior management has a clear vision as to where we are going and } \\
\text { how are going to get there. }\end{array}$ & 4,02 & 4,16 \\
\hline 4 & $\begin{array}{l}\text { If you asked two different people what our strategy is, you would } \\
\text { probably get two different answers. }\end{array}$ & 3,27 & 3,36 \\
\hline 5 & $\begin{array}{l}\text { We are quite willing to spend money, as long as it's for the right } \\
\text { things. }\end{array}$ & 4,06 & 4,04 \\
\hline 6 & Even the man/woman on the shop floor knows the company's vision. & 3,79 & 3,81 \\
\hline & Mean & 3,58 & 3,69 \\
\hline
\end{tabular}




\section{International Journal of Current Science Research and Review}

ISSN: 2581-8341

Volume 04 Issue 12 December 2021

DOI: 10.47191/ijcsrr/V4-i12-27, Impact Factor: 5.825

IJCSRR@ 2021

www.ijcsrr.org

\begin{tabular}{|l|l|l|l|}
\hline No. & Future Orientation Category & Mining SOEs & $\begin{array}{l}\text { Private } \\
\text { Company }\end{array}$ \\
\hline 1 & We consining \\
\hline 2 & We do not invest a lot of resources in R\&D efforts. & 3,92 & 3,95 \\
\hline 3 & $\begin{array}{l}\text { Our company likes to try to create totally new markets based on } \\
\text { innovative products that customers do not even know they need } \\
\text { yet. }\end{array}$ & 3,18 & 3,01 \\
\hline 4 & $\begin{array}{l}\text { We tend to be followers rather than leaders in our product/service } \\
\text { offerings. }\end{array}$ & 2,87 & 3,33 \\
\hline 5 & $\begin{array}{l}\text { Employees are not generally rewarded for experimentation in our } \\
\text { company. }\end{array}$ & 2,50 & 2,92 \\
\hline & \begin{tabular}{l} 
Mean \\
\hline
\end{tabular}
\end{tabular}

Cite this Article: Mayta Kamila (2021). Analysis Corporate Entrepreneurship in SOEs at Mining Sector with Private Companies as Comparative Study. International Journal of Current Science Research and Review, 4(12), 1815-1829 